\section{Epidemiological aspects of enteroparasitosis at daycare centers in the city of Botucatu, State of São Paulo, Brazil}

\section{Aspectos epidemiológicos das enteroparasitoses em creches na cidade de Botucatu, Estado de São Paulo, Brasil}

\author{
Luciene Maura Mascarini ${ }^{1}$ \\ Maria Rita Donalisio \\ 1 Departamento de Parasitologia do Instituto de Biociências da UNESP \\ ${ }^{2}$ Departamento de Medicina Preventiva e Social da Faculdade de Ciências \\ Médicas da UNICAMP
}

\section{Abstract}

Objective: To estimate the prevalence and incidence of intestinal parasites in children and staff members of 5 municipal daycare centers in Botucatu/SP. Two cross-sectional studies were carried out in 2002 $(\mathrm{N}=379)$ and $2003(\mathrm{~N}=397)$ and a longitudinal observational experiment in which the children from 2002 and 2003 were evaluated for a year. Questionnaires were given to staff members and parents of the children, where the following variables were recorded: socioeconomic status, sanitary habits, home, age, gender and presence of domestic animals. Coproparasitologic tests were carried out in child daycare centers. The enteroparasite prevalence was $76.74 \%$ in 2002 and 34\% in 2003. The variables associated with presence of enteroparasites in the investigation carried out in 2002 were: location of daycare centers (OR=0.27 $\mathrm{CI}=0.15-0.47)$; family salary $(\mathrm{OR}=4.38 \mathrm{CI}=1.91-10.04)$; gender $(\mathrm{OR}=0.52$ $\mathrm{CI}=0.32-0.85)$; child's age group $(\mathrm{OR}=2.08$ $\mathrm{CI}=1.06-4.08)$, and presence of pets at home (OR=1.85 CI=1.10-3.11); in 2003, the variables were: daycare centers located in peripheral region $(\mathrm{OR}=0.49 \mathrm{CI}=0.31-0.78)$, family salary $(\mathrm{OR}=3.69 \mathrm{CI}=2.19-6.24)$; mother's education $(\mathrm{OR}=6.19 \mathrm{CI}=1.81$ 21.21); gender $(\mathrm{OR}=0.58 \mathrm{CI}=0.36-0.93)$, and presence of pets $(\mathrm{OR}=1.68 \mathrm{CI}=1.01-2.79)$. The cohort had 253 children with an incidence of $23.22 \%$. Data from this study highlighted situations of risk in specific populations (daycare centers), which could be useful for other childcare institutions.

Keywords: Child. Intestinal parasites. Daycare center. Epidemiology

Financial support: FUNDUNESP (Fundação para o Desenvolvimento da UNESP) Process nº 154/02FFP

Acknowledgements: We are grateful to the employees of the Department of Parasitology for their support in the accomplishment of the copro-parasitologic exams; to the students of the disciplines of Biological Sciences and Nutrition for their help in the meetings and in the collection of information from parents of the children receiving daycare center.

Correspondence: Luciene Maura Mascarini. Departamento de Parasitologia, Instituto de Biociências. Rubião Jr. s/ n. cx. Postal 510, Universidade Estadual Júlio de Mesquita Filho (UNESP) Câmpus de Botucatu, CEP 18.618-100, Botucatu, SP. E-mail: luciene@ibb.unesp.br 


\section{Resumo}

Estimou-se a prevalência e a incidência de parasitas intestinais em crianças e funcionários de 5 creches municipais em Botucatu/SP. Foram realizados dois estudos seccionais em $2002(\mathrm{~N}=379)$ e 2003 $(\mathrm{N}=397)$ e um estudo longitudinal observacional, onde as crianças de 2002 e 2003 foram seguidas por um ano. Foram aplicados questionários nos funcionários e nos pais das crianças, onde foram coletadas as seguintes variáveis: nível sócio-econômico, hábitos sanitários, moradia, idade, sexo e presença de animais domésticos. Foram realizados exames coproparasitológicos nas crianças das creches. A prevalência de enteroparasitas em 2002 foi de 76,74\% e $34 \%$ em 2003 . As variáveis associadas à presença de enteroparasitas no ano de 2002 foram: localização das creches $(\mathrm{OR}=0,27$ $\mathrm{IC}=0,15-0,47)$, renda familiar $(\mathrm{OR}=4,38$ $\mathrm{IC}=1,91-10,04)$, sexo $(\mathrm{OR}=0,52 \mathrm{IC}=0,32$ 0,85), faixa etária $(\mathrm{OR}=2,08 \mathrm{IC}=1,06-4,08) \mathrm{e}$ presença de animais domésticos na casa $(\mathrm{OR}=1,85 \mathrm{IC}=1,10-3,11)$; em 2003, as variáveis foram: creche localizada em bairro periférico $(\mathrm{OR}=0,49 \mathrm{IC}=0,31-0,78)$, renda familiar (OR=3,69 IC=2,19-6,24), nível educacional da mãe $(\mathrm{OR}=6,19 \mathrm{IC}=1,81-21,21)$, sexo $(\mathrm{OR}=0,36 \mathrm{IC}=0,36-0,93)$ e presença de animais domésticos ( $\mathrm{OR}=1,68 \mathrm{IC}=1,01$ 2,79). A coorte foi integrada por 253 crianças apresentando incidência de $23,22 \%$. Os dados deste estudo evidenciam situações de risco em populações específicas (creches) e poderiam ser utilizados por Instituições que promovem o cuidado com as crianças.

Palavras chave: Crianças. Parasitas intestinais. Creches. Epidemiologia.

\section{Introduction}

Enteroparasites display extensive geographical distribution, reaching high prevalence in developing countries. In those countries, the pathogenicity of intestinal parasitic disease intensifies the plight of wide segments of the population living in areas without sanitation, in precarious houses and those submitted to deficient alimentary conditions ${ }^{1}$. Recent estimates indicate that more than one third of the world population is infected by one or more enteroparasites, and that children are the group at greatest risk $^{2-4}$.

Infections caused by helminth (nematode) worms - A. lumbricoides, T. trichiura and Ancilostomatidae - were estimated to encompass 39 million cases, with 10.5, 6.4 and 22.1 million for each worm, respectively, exceeding infections caused by malaria, which reached 35.7 million individuals in the $1990 \mathrm{~s}^{5,6}$.

Since the 1940s, the number of studies seeking to quantify the prevalence of intestinal parasitism in Brazil has been elevated. However, most of this research reflects the reality of small municipalities, complicating the process of obtaining a diagnosis of the overall situation in the country $^{1}$. Several studies carried out in São Paulo, in the 1930s, 40s and 50s, indicated a prevalence of around 55\% for ascaridiasis in the entire population. Yet for ancylostomiasis in students, high rates were found in the municipal district of São Paulo (53\%) and in Ribeirão Preto (87\%), while in the coastal area of the state, $100 \%$ of the individuals were positive for this parasite ${ }^{7}$.

An expressive decline in the frequency of positive exams for ascaridiasis was observed throughout the 1970s, both in the metropolitan area and in the more rural interior of the state. On the other hand, the frequency of positive exams for giardiasis changed little through the whole period studied $^{8}$. In studies conducted in infant populations from the state of São Paulo, there is a clear prevalence of giardiasis, ascaridiasis and tricuriasis among other 
enteroparasitoses ${ }^{4}$; and giardiasis outbreaks are not rare in developed countries, especially in daycare centers and in institutionalized populations ${ }^{9}$. Several researchers have refocused attention on daycare facilities in terms of favorable conditions for the transmission of different intestinal parasites ${ }^{10-13}$.

This study aimed to augment knowledge of ecological and epidemic aspects and also the transmission mechanisms of enteroparasitosis in children less than seven years old institutionalized at daycare centers in the municipal district of Botucatu-SP.

\section{Materials and methods}

The study was carried out in the municipality of Botucatu, located in the central area of the State of São Paulo, Brazil. The population in the urban area is 103,793 residents, while 4,319 individuals reside in the rural portion, totalling 108,112 inhabitants from the 2000 census $^{14}$. The municipal district contains 17 daycare centers: three daycare centers downtown, 12 in the peripheral areas and two rural ones, totalling 1,524 children with about 40-70 children per daycare center.

Two cross sectional studies were conducted in the years 2002 ( $\mathrm{N}=379$ children) and 2003, ( $\mathrm{N}=397$ children) and a cohort longitudinal observational study, in which the children present in 2002 and 2003 ( $N=253$ ) formed the cohort. The unit of research was the daycare center. Stratified random sampling of the daycare centers in the municipal district was conducted, to guarantee the proportional representation of the areas: central, rural and peripheral. Five institutions of the municipal district were chosen: one in the rural area the daycare center at Vitoriana) and four in the urban area (one in the central area daycare center 'AAMI' - and three in the area peripheral to the city: Horestes Spadotto, Cohab and Jardim Flamboyant).

The sample size of children was calculated by taking into account the entero- parasitosis prevalence observed in previous studies ${ }^{15,16}$, which indicated variations in prevalence from 51 to $97 \%$, being established at $50 \%$, with variation of $\pm 5 \%$, standard error of $5 \%$, and confidence interval of $95 \%$. Three samples of each child's feces were collected by fecal pools, where coproparasitologic exams were conducted by the methods of Faust et al. , Hoffman, Pons and Janer, the adhesive methods of Ribbon (Graham method) and Rithie's Method, where slides were made for specific diagnosis of Cryptosporidium sp. (Ziehl-Neelsen method). Questionnaires were given to employees and parents, or others responsible for the children, by which data for the following variables were collected: socioeconomic status, sanitary habits, home, age, gender and presence of domestic animals. Univariate $\left(\mathrm{X}^{2}\right)$ and multivariate (multiple regression logistics) analyses were performed ${ }^{17}$ (using SAS statistical program) where the dependent variable was the presence of enteroparasites and the explicit variables were socioeconomic conditions, sanitary conditions, habits, home conditions, age and gender.

Informed consent was obtained from the parents or legal guardians of each child prior to enrollment, and the study was approved by the Research Ethics Committee of the School of Medicine, State University of São Paulo (UNESP), Brazil (of.110/2002CEP).

\section{Results}

In the 2002 study, 379 children were analyzed, and the prevalence coefficient for enteroparasites (one or more) for 100 children was $50.39 \%$, whereas in 2003 , the prevalence coefficient for enteroparasitosis of $34 \%$ was verified in 397 children (Table 1). The daycare centers analyzed in 2002 and 2003 were statistically different for the presence of enteroparasites $\left(\chi^{2}=40.74\right.$ and $\mathrm{p}<0.001$ in 2002 and $\chi^{2}=39.51$ and $\mathrm{p}<0.001$ in 2003), in which the Vitoriana daycare center stands out 
with the highest prevalence $(76.74 \%$ in 2002 and $51.32 \%$ in 2003 ) of enteroparasitosis.

In 2002 the following variables were shown to be relevant ( $\mathrm{p}<0.05$ ): gender, age group, location of dwelling, income, mother's education, type of housing, and drinking water (Table 2). The boys attending daycare centers showed a higher prevalence of enteroparasitosis $(\mathrm{OR}=1.80$ IC $=1.19-2.70)$. In the 72-83 month age group ( $>6$ years) children presented a higher prevalence $(84.37 \%$ and $\mathrm{OR}=6.03$ $\mathrm{IC}=2.14-18.28$ ) of parasites than children from other age groups. In the analysis of housing conditions, the variable 'location of dwelling' evidenced greater prevalence of parasites in children that lived in the rural area $(\mathrm{OR}=1.71 \mathrm{IC}=1.42-2.05)$, while in the variable 'type of housing', children who lived in wooden huts also presented elevated prevalence in enteroparasitosis acquisition $(\mathrm{OR}=4.38 \mathrm{IC}=1.87-10.30)$. The presence of enteroparasites in children was inversely proportional to family income; and the stratum 'smaller than two minimum wages' showed a higher prevalence $(67.14 / \%)$ of positive tests when compared to the other income levels. A decrease in enteroparasitosis prevalence was evidenced as mother's education levels increased. Elevation of the prevalence coefficient was verified at the lowest levels of maternal education (level $1=63.19 \%$; $\mathrm{OR}=2.49 \mathrm{IC}=1.59-3.89$ ). The water ingested (variable 'drinking water') showed greater prevalence in enteroparasitosis acquisition in the children that ingested water without in-home treatment $(\mathrm{OR}=1.89 \mathrm{IC}=1.22$ 2.92).

In 2003, the following variables were relevant ( $\mathrm{p}<0.05$ ): gender, location of dwelling, income, mother's education and type of housing (Table 3). As to gender, boys showed a higher prevalence than girls $(\mathrm{OR}=1.32 \mathrm{IC}=1.00-1.75)$. For the variable 'location of dwelling' the children from the rural area evidenced greater prevalence of parasitosis ( $\mathrm{OR}=2.48 \mathrm{IC}=1.59-3.85)$, while in the variable 'type of housing', the children that lived in wooden huts also presented a high prevalence of enteroparasites $(\mathrm{OR}=2.90 \mathrm{IC}=1.49-5.65)$. The prevalence of enteroparasitosis was inversely proportional to the increase in income and the stratum 'smaller than two minimum wages' showed a higher prevalence $(\mathrm{OR}=3.81$ IC $=2.27-6.38$ ) when compared to the other levels of income. The variable 'mother's education' presented a decrease in the parasitosis prevalence as education levels increased $(\mathrm{OR}=2.12 \mathrm{IC}=1.38-3.24)$ and a prevalence coefficient of $43.33 \%$ was observed at one level (without formal education and less than eight years of education).

Models of multivariate logistic regression were adjusted for analyses of 2002 and 2003. In 2002 (Table 4) the following variables were found: daycare center, income one and two, female gender, age group less than seven years and presence of domestic animals. The variables 'income one' $(\mathrm{p}=0.005)$ (smaller than two wages) and 'in-

Table 1 - Prevalence of enteroparasites in five daycare centers in de the city of Botucatu, State of São Paulo, Brazil, 2002 and 2003.

\begin{tabular}{lcccccc}
\hline DAYCARE CENTERS & \multicolumn{2}{c}{ No $^{\circ}$} & \multicolumn{2}{c}{ No $^{\circ}$} & \multicolumn{2}{c}{ COEFFICIENT } \\
& 2002 & 2003 & $2002^{\mathrm{a}}$ & $2003^{\mathrm{b}}$ & 2002 & 2003 \\
\hline Horestes Spadoto (VF) & 43 & 73 & 27 & 26 & 62.79 & 35.61 \\
Vitoriana (VI) & 86 & 113 & 66 & 58 & 76.74 & 51.32 \\
AAMI (VL) & 90 & 65 & 31 & 04 & 34.44 & 6.15 \\
Cohab (CO) & 62 & 48 & 24 & 19 & 38.71 & 39.58 \\
J. Flamboyant (JF) & 98 & 98 & 43 & 28 & 43.88 & 28.57 \\
TOTAL & 379 & 397 & 191 & 135 & 50.39 & 34.0 \\
\hline${ }^{\mathrm{a}} \chi^{2}=40.74(\mathrm{p}<0.001) ;{ }^{\mathrm{b}} \chi^{2}=39.61(\mathrm{p}<0.001)$ & & & & & &
\end{tabular}


Table 2 - Univariate analysis between dependent variable (result = positive/negative) and covariates in children of daycare centers in the city of Botucatu, State of São Paulo, Brazil, 2002.

\begin{tabular}{|c|c|c|c|c|c|}
\hline \multirow[t]{3}{*}{ Covariates } & \multicolumn{5}{|c|}{ Dependent variable } \\
\hline & $\chi^{2}$ & $\mathrm{p}$ & Coefficient & $\mathrm{OR}^{1}$ & $\mathrm{IC}^{2}$ \\
\hline & & & prevalence /100 & & $95 \%$ \\
\hline Sex & 7.96 & 0.005 & & & \\
\hline Boys & & & 57.14 & 1.80 & $1.19-2.70$ \\
\hline Girls & & & 42.61 & & \\
\hline Age group (class) & 20.85 & $<0.001$ & & & \\
\hline Nursery $(0-24)^{3}$ & & & 52.43 & 1.11 & $0.66-1.86$ \\
\hline Mini-group(25-39) & & & 46.15 & 0.84 & $0.55-1.29$ \\
\hline Maternal (40-52) & & & 48.25 & 0.83 & $0.55-1.27$ \\
\hline Kindergarten (53-71) & & & 31.57 & 0.42 & $0.19-0.90$ \\
\hline Pre-school (72-83) & & & 84.37 & 6.03 & $2.14-18.28$ \\
\hline Location of dwelling & 26.08 & $<0.001$ & & & \\
\hline Rural area & & & 72.29 & 1.71 & $1.42-2.05$ \\
\hline Urban area & & & 42.75 & & \\
\hline Income 4 & 9.95 & 0.002 & & & \\
\hline$<2$ wages & & & 67.14 & 2.17 & $1.21-3.91$ \\
\hline 2 a 4 wages & & & 50.63 & 0.84 & $0.53-1.34$ \\
\hline$>4$ wages & & & 38.46 & 0.52 & $0.27-0.99$ \\
\hline Mother's education & 15.82 & $<0.001$ & & & \\
\hline Level $1^{5}$ & & & 63.09 & 2.49 & $1.59-3.89$ \\
\hline Level $2^{6}$ & & & 41.53 & 0.63 & $0.35-1.11$ \\
\hline Level $3^{7}$ & & & 40.31 & 0.56 & $0.35-0.88$ \\
\hline Type of housing & 13.24 & $<0.001$ & & & \\
\hline Wooden huts & & & 80.55 & 4.38 & $1.87-10.30$ \\
\hline Masonry & & & 48.58 & & \\
\hline Water & 8.16 & 0.004 & & & \\
\hline Treatment $2^{8}$ & & & 61.53 & 1.89 & $1.22-2.92$ \\
\hline Treatment 19 & & & 45.88 & & \\
\hline
\end{tabular}

${ }^{1} \mathrm{OR}=$ Odds ratio ${ }^{2} \mathrm{IC}=$ confidence intervals ${ }^{3}$ months of life ${ }^{4}$ Income in minimum wages of Brazil

${ }^{5}$ Level $1=$ without formal education and incomplete fundamental education

${ }^{6}$ Level 2 = complete fundamental education and incomplete high school

${ }^{7}$ Level 3 = complete high school and higher education (complete higher education)

${ }^{8}$ Treatment 2 = water without home treatment (SABESP)

${ }^{9}$ Treatment 1 = water with home treatment

come two' ( $\mathrm{p}=0.032$ ) (two to four minimum wages) presented relevance; and the chance of presenting parasitosis was higher in income one $(\mathrm{OR}=4.38 \mathrm{IC}=1.91$ 10.04), decreasing in income $2(\mathrm{OR}=2.08$ $\mathrm{IC}=1.06-4.08)$. For the variable 'gender', female was detected as a 'protection factor' (OR=0.52 IC=0.32-0.85) when compared to male children. The preschool group (children younger than seven years) presented a higher prevalence $(\mathrm{OR}=2.08$ $\mathrm{IC}=1.06-4.08$ ) when compared with other groups. The presence of domestic animals (variable 'animals') indicated that children who have domestic animals present greater prevalence $(\mathrm{OR}=1.85 \mathrm{IC}=1.10-3.11)$ of enteroparasites, compared to children that do not have such animals.

In 2003, (Table 5) the variables daycare center, income, gender, mother's education and presence of domestic animals were studied. The 'Horestes Spadotto' daycare center presented a smaller enteroparasites prevalence coefficient compared to the other studied daycare centers (OR=0.49 IC=0.31-0.78) and was considered to be a 'protection variable' for a positive exam. The variable 'income one' $(<2$ 
Table 3 - Univariate analysis between dependent variable (result = positive/negative) and covariates in children of daycare centers in the city of Botucatu, State of São Paulo, Brazil, 2003.

\begin{tabular}{|c|c|c|c|c|c|}
\hline \multirow[t]{2}{*}{ Covariates } & \multicolumn{5}{|c|}{ Dependent variable } \\
\hline & $\chi^{2}$ & $\mathrm{p}$ & $\begin{array}{c}\text { Coefficient } \\
\text { prevalence /100 }\end{array}$ & $\mathrm{OR}^{1}$ & IC $-95 \%^{2}$ \\
\hline Sex & 3.89 & 0.048 & & & \\
\hline Boys & & & 38.61 & 1.32 & $1.00-1.75$ \\
\hline Girls & & & 29.23 & & \\
\hline Age group (class) ${ }^{3}$ & 3.21 & 0.523 & & & \\
\hline Nursery $(0-24)$ & & & 33.33 & 0.96 & $0.55-1.68$ \\
\hline Mini-group (25-39) & & & 39.58 & 1.32 & $0.68-2.55$ \\
\hline Maternal (40-52) & & & 33.33 & 0.95 & $0.61-1.48$ \\
\hline Kindergarten (53-71) & & & 20.0 & 0.47 & $0.15-1.35$ \\
\hline Pre-school (17-83) & & & 39.9 & 1.18 & $0.69-2.0$ \\
\hline Location of dwelling & 16.62 & $<0.001$ & & & \\
\hline Rural area & & & 48.38 & 2.48 & $1.59-3.85$ \\
\hline Urban area & & & 27.47 & & \\
\hline Income ${ }^{4}$ & 31.19 & $<0.001$ & & & \\
\hline$<2$ wages & & & 58.70 & 3.81 & $2.27-6.38$ \\
\hline 2 a 4 wages & & & 27.84 & 2.26 & $1.44-3.54$ \\
\hline$>4$ wages & & & 23.25 & 0.54 & $0.24-1.18$ \\
\hline Mother's education & 19.95 & $<0.001$ & & & \\
\hline Level $1^{5}$ & & & 43.33 & 2.12 & $1.38-3.24$ \\
\hline Level $2^{6}$ & & & 37.65 & 1.21 & $0.73-1.99$ \\
\hline Level $3^{7}$ & & & 19.05 & 0.33 & $0.20-0.55$ \\
\hline Type of housing & 10.49 & $<0.001$ & & & \\
\hline Wooden huts & & & 57.50 & 2.90 & $1.49-5.65$ \\
\hline Masonry & & & 31.79 & & \\
\hline
\end{tabular}

${ }^{1} \mathrm{OR}=$ Odds ratio ${ }^{2} \mathrm{IC}=$ confidence intervals ${ }^{3}$ month of year ${ }^{4}$ Income in minimum wages of Brazil

${ }^{5}$ Level $1=$ without formal education and incomplete fundamental education

${ }^{6}$ Level $2=$ complete fundamental education and incomplete high school

${ }^{7}$ Level $3=$ complete high school and higher education (complete higher education)

minimum wages) presented a significant difference $(\mathrm{p}<0.0001)$ with $\mathrm{OR}=3.70$ (IC=2.19-6.24) for the presence of positive exams, when compared to other incomes. The analysis detected femaleness as a protection factor, as was the presence of enteroparasites, with OR 0.58 ( $\mathrm{IC}=0.36$ 0.93) when compared to male children. Children with domestic animals showed the highest prevalence $(\mathrm{OR}=1.68 \mathrm{IC}=1.01$ 2.79) of all those presenting enteroparasites. The variable 'mother's education one' (without formal education) was significantly different $(\mathrm{p}=0.0037)$ from other education levels, with $\mathrm{OR}=6.20(\mathrm{IC}=1.81$ 21.23).

The children's group whose follow-up was completed in one year (2002 and 2003) was comprised of the cohort with 253 children, distributed among the five municipal daycare centers: Horestes Spadotto VF (9.48\%,), Vitoriana -VI (14.62\%), AAMI - VL (18.19\%), Cohab - CO (18.98\%) and Jardim Flamboyant -JF (38.73\%).

The estimated enteroparasitosis incidence in the study period was $23.32 \%$. Incident cases were considered as the negative cases from 2002 that became positive in 2003 (new cases), and the positive cases in 2002 that received specific treatment (conducted by the Health Service of the municipal district of Botucatu/SP) and turned negative and positive again in 2003 (cases of reinfection).

The risks of acquiring enteroparasites, according to some variables considered 
Table 4 - Multivariate analysis in significant variables in children of daycare centers in the city of Botucatu, State of São Paulo, Brazil, 2002.

\begin{tabular}{|c|c|c|c|c|}
\hline Covariates & $\beta$ & $\mathrm{OR}^{1}$ & IC - $(95 \%)^{2}$ & $\mathrm{p}$ \\
\hline \multicolumn{5}{|l|}{ Daycare centers ${ }^{3}$} \\
\hline COJFVL & -1.3028 & 0.27 & $0.16-0.47$ & $<0.001$ \\
\hline VI e VF & - & 1.0 & - & - \\
\hline Income 14 & 1.4779 & 4.38 & $1.91-10.04$ & $<0.001$ \\
\hline Incomes ( 2 e 3 ) & - & 1.0 & - & - \\
\hline Income $2^{5}$ & 0.7345 & 2.08 & $1.06-4.08$ & 0.032 \\
\hline Incomes ( 1 e 3 ) & - & 1.0 & - & - \\
\hline \multicolumn{5}{|l|}{ Sex } \\
\hline Girls & -0.6440 & 0.52 & $0.32-0.85$ & 0.008 \\
\hline Boys & - & 1.0 & - & - \\
\hline \multicolumn{5}{|l|}{ Age group ${ }^{6}$} \\
\hline Pre-school & 1.1992 & 2.08 & $1.06-4.08$ & 0.048 \\
\hline N/MG/M/G (Other groups) & - & 1.0 & - & - \\
\hline \multicolumn{5}{|l|}{ Pets } \\
\hline Presence & 0.6140 & 1.85 & $1.10-3.11$ & 0.028 \\
\hline Absence & - & 1.0 & - & - \\
\hline
\end{tabular}

${ }^{1} \mathrm{OR}=$ Odds ratio ${ }^{2} \mathrm{I} C=$ Confidence interval

${ }^{3} \mathrm{COJFVL}=$ three daycare centers in peripheral and central location with good living conditions. $\mathrm{VI}$ and $\mathrm{VF}=$ daycare center in rural area and peripheral location.

${ }^{4}$ Income $1=$ income $>2$ minimum wages of Brazil

${ }^{5}$ Income 2 =income $<2$ and $>4$ minimum wages of Brazil. Income $3=$ income $<4$ minimum wages of Brazil.

${ }^{6} \mathrm{Age}$ group $=$ pre school (71-83 months). Other groups = nursery/mini-group/maternal and Kindergarten.

Table 5 - Multivariate analysis in significant variables in children of daycare centers in the city of Botucatu, State of São Paulo, Brazil, 2003.

\begin{tabular}{lcccc}
\hline Covariates & $\beta$ & OR $^{1}$ & IC- 95\% ${ }^{2}$ & $\mathrm{p}$ \\
\hline Daycare centers ${ }^{3}$ & & & & \\
VF & -0.716 & 0.49 & $0.31-0.78$ & 0.003 \\
VI, JF,CO,VL & - & 1.0 & - & - \\
Income 1 ${ }^{4}$ & 1.307 & 3.69 & $2.19-6.24$ & $<0.001$ \\
incomes (2 e 3) & - & 1.0 & - & - \\
E1 ${ }^{5}$ & 1.824 & 6.19 & $1.81-21.23$ & 0.003 \\
E2, E3 e E4 & - & 1.0 & - & - \\
Sex & & & & 0.024 \\
Girls & -0.539 & 0.58 & $0.36-0.93$ & - \\
Boys & - & 1.0 & - & 0.045 \\
Pets & & 1.68 & $1.01-2.79$ & - \\
Presence & 0.520 & 1.0 & - & \\
Absence & - & & & \\
\hline
\end{tabular}

${ }^{1} \mathrm{OR}=$ Odds ratio ${ }^{2} \mathrm{IC}=$ Confidence interval

${ }^{3} \mathrm{VF}=$ daycare center in peripheral location with good living conditions

$\mathrm{VI}, \mathrm{JF}, \mathrm{CO}$ e $\mathrm{VL}=$ daycare center in rural area / peripheral location/central location

${ }^{4}$ Income $1=$ income $<2$ minimum wages, income $2=$ income $<2$ a $>4$ minimum wages and income $3=>4$ minimum wages.

${ }^{5} \mathrm{E} 1=$ Mother's education level 1 = without formal education, $\mathrm{E} 2=$ complete fundamental education and $\mathrm{E} 3=$ complete high school, E4 = higher education (complete higher education). 
relevant, are shown in Table 6 . Children attending the Vitoriana daycare center showed a higher incidence of enteroparasites $(40.54 \%)$ with $\mathrm{RR}=6.22$ ( $\mathrm{IC}=1.95$ 19.85). The standard for incidence in children was the AAMI daycare center. Family income of children from daycare centers was inversely proportional to the incidence of enteroparasites. The ones with income 'lower than two minimum wages' presented a higher risk $(\mathrm{RR}=2.03 \mathrm{IC}=1.10-3.75)$, and this risk decreased in higher incomes.
Girls presented a higher incidence of enteroparasites $(25.76 \%)$ than boys (20.66\%). The variables that included 'location of dwelling' and 'type of housing' were relevant, while children that lived in the rural area presented an incidence of $35.56 \%$ and a risk of enteroparasitosis acquisition ( $R R=1.72$ IC:1.07-2.77) higher than that of urban children. For 'type of housing', children living in wooden huts presented an enteroparasitosis incidence of $31.58 \%(\mathrm{RR}=1.34 \mathrm{IC}=0.66-2.72)$ com-

Table 6 - Proportion of incidence and relative risk (RR) of enteroparsitoses in cohort of children of daycare center in the city of Botucatu, State of São Paulo, in 2002 and 2003.

\begin{tabular}{|c|c|c|c|c|c|}
\hline Covariates & $\begin{array}{l}\text { Proportion of } \\
\text { Incidence \% }\end{array}$ & $\chi^{2}$ & $p^{1}$ & $\mathrm{RR}^{2}$ & IC $(95 \%)^{3}$ \\
\hline Daycare center & & 15.58 & 0.003 & & \\
\hline H. Spadotto (VF) & 33.33 & & & 5.11 & $1.49-17.52$ \\
\hline Vitoriana (VI) & 40.54 & & & 6.22 & $1.95-19.86$ \\
\hline Cohab (CO) & 27.08 & & & 4.15 & $1.27-13.63$ \\
\hline J.Flamboyant (JF) & 20.41 & & & 3.13 & $0.98-10.0$ \\
\hline AAMI (VL) & 6.52 & & & & \\
\hline Sex & & 0.92 & 0.34 & & \\
\hline Girls & 25.75 & & & 1.25 & $0.79-1.96$ \\
\hline Boys & 20.66 & & & & \\
\hline Age group & & 3.29 & 0.51 & & \\
\hline Nursery $(0-24)^{4}$ & 21.21 & & & 1.77 & $0.55-5.63$ \\
\hline Mini-group(25-39 & 23.08 & & & 1.92 & $0.54-6.87$ \\
\hline Maternal (40-52) & 25.78 & & & 2.15 & $0.71-6.46$ \\
\hline Preschool (71-83) & 37.5 & & & 3.13 & $0.78-12.52$ \\
\hline Kindergarten(53-71) & 12.0 & & & & \\
\hline Location of dwelling & & 4.58 & 0.03 & & \\
\hline Rural & 35.56 & & & 1.72 & $1.07-2.77$ \\
\hline Urban & 20.67 & & & & \\
\hline Type of housing & & 0.62 & 0.43 & & \\
\hline Wooden huts & 31.58 & & & 1.34 & $0.66-2.72$ \\
\hline Masonry & 23.50 & & & & \\
\hline Income ${ }^{5}$ & & 5.27 & 0.071 & & \\
\hline$<2$ wages & 36.36 & & & 2.03 & $1.10-3.75$ \\
\hline 2 a 4 wages & 21.02 & & & 1.17 & $0.56-4.40$ \\
\hline$>4$ wages & 17.95 & & & & \\
\hline Mother's education & & 3.13 & 0.21 & & \\
\hline Level $1^{6}$ & 29.36 & & & 1.55 & $0.93-2.57$ \\
\hline Level $2^{7}$ & 21.95 & & & 1.16 & $0.57-2.36$ \\
\hline Level $3^{8}$ & 18.95 & & & & \\
\hline \multicolumn{6}{|c|}{$\begin{array}{l}\text { I } p<0.05 \\
{ }^{2} R R=\text { Relative Risk }{ }^{3} \mathrm{C}=\text { Confidence Interval }{ }^{4} \text { months of life } \\
\text { Income in minimum wages of Brazil } \\
\text { 6Level } 1=\text { without formal education and incomplete fundamental education } \\
\text { 'Level } 2=\text { complete fundamental education and incomplete high school } \\
{ }^{8} \text { Level } 3=\text { complete high school and incomplete and complete higher education }\end{array}$} \\
\hline
\end{tabular}


pared to children that lived in masonry houses. The variable 'mother's education' was inversely proportional to the incidence of enteroparasites, and 'education level one' (without formal education and incomplete primary school) was the range that presented a higher incidence proportion $(29.36 \%)$ of enteroparasites and a higher relative risk $(\mathrm{RR}=1.55 \mathrm{IC}=0.93-2.31)$, compared to other education levels.

\section{Discussion}

The growing diffusion, in recent decades, of services for children in daycare centers or school-like institutions has been a source of new studies. Besides the natural vulnerability of that age group, the users of child daycare centers are more likely to acquire and develop infections, especially of the repetitive type such as respiratory and gastrointestinal ones.

The collective environment of daycare centers facilitates large circulation and transmission of pathogenic agents ${ }^{18,19}$. Collective environments with many children agglomerated in closed places, without appropriate hygienic conditions facilitate the spread and persistence of enteroparasitosis in daycare centers, schools and orphanages enabling special epidemiology of transmission ${ }^{12,20-22}$.

In the study conducted in 2002, the prevalence coefficient of enteroparasitosis in daycare centers varied from $76.74 \%$ in the rural daycare centers to $34.44 \%$ in the urban ones (central and peripheral). In the 2003 study, prevalence in the rural daycare centers decreased to $51.32 \%$, while in the urban ones, the minimum observed was $6.15 \%$. The enteroparasitosis incidence observed in the cohort (period of one year) was $23.32 \%$, with the incidence at the Vitoriana daycare center standing out at $40.54 \%$ and $\mathrm{RR}=6.22$ (IC=1.95-19.86) compared to the other daycare centers.

Among daycare centers in several Brazilian cities, the prevalence of enteroparasitosis varies greatly, reaching the highest values in the State of São Paulo in which the city of Botucatu presented $71.5 \%$ and Mirassol $63.9 \%^{13,23}$; in the state of Goiás, the city of Goiânia showed $69 \%^{24}$, while in the state of Sergipe, the city of Aracaju had $56.6 \%{ }^{25}$; the decrease continued in the state of Paraná, in which the city of Rolândia showed $15.2 \%^{26}$. The results found at Botucatu daycare centers in 2002 evidenced that enteroparasitosis continues to be a public health problem in those institutions, both in urban daycare centers and in rural ones, with a decline in the year of 2003, a reduction already expected since the children of the study were referred to the Municipal Health Center where they received specific treatment.

In the city of São Paulo, an effective decline was observed in the prevalence of helmintosis and of giardiasis, due to improvements verified in the city regarding housing conditions ${ }^{4}$. Certain aspects inherent to daycare services are considered factors that favor entericpathogenic transmission, such as: the grouping of people in a situation of daily and prolonged coexistence (10-12 hours), prolonged physical contact, both adult-child and child-child contact, which have unfolded into various care and educational activities ${ }^{16,27,28}$.

The boys presented a higher prevalence of parasitism OR=1.80 (IC=1.19-2.70) in 2002 and $\mathrm{OR}=1.32(1.00-1.75)$ in 2003, than did the girls. In the cohort study this difference between genders was not detected ( $p>0.05$ ), suggesting that when boys and girls are submitted to the same conditions of coexistence in the daycare center environment, as they were after the treatment conducted at the end of 2002, the opportunity for enteroparasitism acquisition is equal for both genders. Differences between boys and girls are reported occasionally, with a higher level of infection for boys than girls ${ }^{4,29,30}$. The prevalence found by several authors is smaller among children from four months to two years, increasing progressively until the 56 year-old age range ${ }^{4,31,32}$. The growing levels of prevalence for age observed in this study are probably related to the growth process and infant development (mobility 
and interaction with the environment) and to the longer time of exposure to environmental conditions. The nursery group for 2002, aged four months to two years, was found to present the highest prevalence after preschool, a fact which highlights the particular conditions observed in the daycare center environment. Studies report that children's immunological immaturity before six months of age and their dependence on the care of strangers, among other factors, make them more susceptible to injuries of any kind, while the occurrence of parasitism in children in the first months of life has already been reported ${ }^{32,33}$.

Throughout the history of enteroparasitosis, the rural environment has always shown the highest enteroparasite prevalence, due to several factors, such as prolonged contact with soil, precarious conditions of environmental sanitation including deficiency in the water supply channel (not always present) and inadequate destinations for feces, intimate contact with domestic animals that are potential vehicles for transmission of enteroparasites and others ${ }^{34,35}$. An association was verified between the location of dwelling (rural area) and presence of enteroparasites in $2002(\mathrm{OR}=1.71$; $\mathrm{IC}=1.42$ 2.05) and in $2003(\mathrm{OR}=2.48$; $\mathrm{IC}=1.59-3.85)$. The Vitoriana daycare center, the only representative of the rural area, was the one that presented both higher prevalence in both studies and a higher incidence, with an incidence proportion of $40.54 \%$ and $\mathrm{RR}=6.22$ ( $\mathrm{IC}=1.95-19.86$ ) compared to the other daycare centers.

The inverse relationship between enteroparasitism and both the level of maternal education and income found in this study was corroborated by increases conducted previously at daycare centers and preschools, which associated the high prevalence of parasitic infections with the low socioeconomic and cultural level of the population ${ }^{13,36}$. Trend analysis of enteroparasitoses in the city of São Paulo, in the State of São Paulo (Brazil) stated that family income and maternal education had a considerable impact on the decline of the prevalence of helmintosis and giardiasis ${ }^{4}$.

Water ingestion is indicated by several authors as a main vehicle of enteroparasitosis transmission ${ }^{37,38}$, either by ingestion or by irrigation of foods with water polluted by human feces. In studies of factors involved in the spread of enteroparasites, the water supplied by municipal services revealed contamination of water in several areas of Brazil ${ }^{39,40}$. In the city of Botucatu, State of São Paulo (Brazil), information supplied by the municipal water service revealed that the drinking water supply in the city, including $100 \%$ of the neighborhoods and serving the entire population, is considered of very good quality (Health's Ministry, Regulation 518/GM). The fact that the population studied presented significant prevalence of enteroparasitosis even when receiving treated water and having appropriate disposal of feces, suggests association of parasitosis not only with sanitary conditions. Such a fact would explain why many programs for the improvement of sanitary conditions through the installation of sewers and water supply by health organizations do not always influence the prevalence of verminosis in those areas ${ }^{41}$.

Studies have reported the common occurrence of Giardia sp. and Cryptosporidium sp. in pets including dogs and cats $^{42-45}$, a situation considered a public health problem due to the zoonotic potential $^{46}$. G. duodenalis and Cryptosporidium sp. are two protozoa that infect a great number of vertebrate hosts. Both are transmitted by direct fecal-oral contact or by the ingestion of food or water contaminated with infectious forms. The description of similar organisms infecting humans and a great variety of mammals and birds prompted several authors to posit that both parasites may have high zoonotic potential $^{47-49}$. Despite the many findings, the zoonotic potential of G. duodenalis and Cryptosporidium sp remains debatable and requires further studies on cross transmission and genotypes of the different species of these two protozoa ${ }^{50}$. 


\section{Conclusion}

This study presents some data that evidence high-risk situations for populations attending daycare centers in the municipality of Botucatu, State of São Paulo. The results can be used in the future planning and optimization of municipal resources allocated to health and in the prevention of diseases that respond to educational actions, as in the case of enteroparasitosis.

\section{References}

1. Waldman EA, Silva LJ, Monteiro CA. A Trajetória Das Doenças Infecciosas. In: Monteiro, C.A. Velhos e Novos males da Saúde no Brasil. $2^{\text {a }}$ edição aumentada. São Paulo: HUCITEC, NUPENS/USP; 2000. pp.195-244.

2. Crompton DWT, Savioli L. Intestinal parasitic infections and urbanization. Bull World Health Organ 1993; 17: 1-7.

3. Warren KS. Helmintic Infection. In: Jamison, D.T. Disease Control Priorities in Developing Countries. Oxford: Medical Publications/University Press; 1993. p.131-60.

4. Ferreira UM, Ferreira CS, Monteiro CA. Tendência secular das parasitoses intestinais na infância na cidade de São Paulo (1984-1996). Rev Saude Publica 2000; 34 (6 S): 73-83.

5. Stephenson LS, Lathan V, Holland CV, Cooper ES. The public health significance of Trichuris trichiura. Parasitology 2000; 121: S73-S95.

6. Crompton DWT. Ascaris and Ascariasis. Adv Parasitol 2001; (48): 285-375.

7. Pessoa, S. B. Endemias parasitárias da zona rural brasileira. São Paulo: Fundo Editorial PROCIENX; 1963.

8. Chieffi PP, Waldman EA, Dias RMDS, Torres DMAGV, Chimara R, Mizumoto LC. Enteroparasitas no município de Guarulhos, SP, Brasil. 1. Prevalência de infeccção entre escolares residentes no bairro de Taboão, em junho de 1984. Rev Inst A Lutz 1988; 48(1/2): 75-80.

9. Keistone JS, Yang J, Grisdale D. Intestinal parasites in metropolitan Toronto day-care centers. Can Med Assoc J 2001; 131: 733-5.

10. Guimarães SE, Sogayar MIL. Blastocystis hominis: occurrence en children and staff members of municipal day-care centers from Botucatu, São Paulo state, Brazil. Mem Inst Oswaldo Cruz 1993; 88: 427-9.

11. Guimarães SE, Sogayar MIL. Ocurrence of Giardia lamblia in children of municipal day-care centers from Botucatu, São Paulo state, Brazil. Rev Inst Med Trop São Paulo 1995; 37: 501-6.

12. Franco RMB, Cordeiro NS. Giardiose e criptosporidiose em creches no município de Campinas, SP. Rev Soc Bras Med Trop 1996; 29: 585-91.
13. Machado RC, Marcari EL, Cristante SFV, Carareto CMA. Giardíase e helmintíases em crianças de creches e escolas de $1^{\circ} \mathrm{e} 2^{\circ}$ graus (públicas e privadas) da cidade de Mirassol (SP, Brasil). Rev Soc Bras Med Trop 1998; 32(6): $1-12$.

14. IBGE. Instituto Brasileiro de Geografia e Estatística. Dados em pesquisa populacional brasileira. Available from URL: http:WWW/home/estatística/população/ estimativa 2004> Accessed 10 October 2004.

15. Mascarini LM, Yoshida ELA. Prevalência de parasitas intestinais, com ênfase em Cryptosporidium sp., em creche municipal de Botucatu/SP. In: XVI CONGRESSO BRASILEIRO DE PARASITOLOGIA; 1999. Poços de Caldas. Minas Gerais; 176.

16. Andrade JB, Mascarini LM. Prevalência de enteroparasitas e padrão nutricional em crianças de creches municipais de Botucatu/SP. J Bras Patologia 2001; 37(4S): 509.

17. SAS Institute. SAS/STAT User's guide, release 8.02. Cary: SAS Institute; 2002.

18. Fuchs SC, Maynart RC, Costa LF, Cadozo A, Schierholt R. Duration of day-care attendance and acute respiratory infection. Cad Saude Publica 1996; 12: 291-6.

19. Barros AJ, Ross DA, Fonseca WV, Williams LA, MoreiraFilho DC. Preventing acute respiratory infections and diarrhoea in child care centers. Acta Pediatr 1999; 88: 1113-8.

20. Moretti IG, Chieffi PP, Nakagawa E, Gomes AC, Foizer ACM. Contribuição ao estudo da história natural de enteroparasitoses em uma comunidade fechada. Rev Soc Bras Med Trop 1974; 8: 41-4.

21. Pinheiro MFS, Marzochi MCA, Giuliano R, Giuliano LG. Enteroparasitoses em uma comunidade fechada. I. Estudo do solo como elo de transmissão em um orfanato de Manaus, Amazonas, Brasil. Acta Amaz 1976; 7: 503-6.

22. Song H, Cho C, Kim J, Choi M, Hong S. Prevalence and risk factors for enterobiasis among preschool children in a metropolitan city in Korea. Parasitol Res 2003; 91: 46-50.

23. Mascarini LM, Yoshida ELA. Prevalência de enteroparasitas em creches da prefeitura municipal de Botucatu-SP, com ênfase em Cryptosporidium sp. J Bras Patologia 2000; 137(4 S): 510. 
24. Santos MAQ, Paçô JM, Isac E, Alves EL, Vieira MA. Prevalência estimada de parasitas intestinais em escolares de creches e estabelecimentos de ensino em Goiânia- Goiás. Rev Pat Trop 1990; 19: 35-42.

25. Cardoso GS, Santana ADC, Aguiar CP. Prevalência e aspectos epidemiológicos da giardíase em creches do município de Aracaju, SE, Brasil. Rev Soc Bras Med Trop 1995; 28(1): 25-31.

26. Giraldi N, Vidotto O, Navarro IT, Garcia JL. Enteroparasites prevalence among day care and elementary school children of municipal schools, Rolandia, PR, Brazil. Rev Soc Bras Med Trop 2001; 34(4): 385-7.

27. Régnier F, Floret D. Mésures préventives d'hygiène dans les crèches. Arch Pédiatr 1999; 6(3): 636-8.

28. Gendrel D. Infections digestives et crèches. Arch Pédiatri 1999; 6(3): 628-32.

29. Dorea RCC, Salata E, Padovani CRB, Anjos GL. Control of parasitic infections among school children in the periurban area of Botucatu, São Paulo, Brazil. Rev Soc Bras Med Trop 1996; 29(5): 425-30.

30. Prado MS, Barreto ML, Strina A, Faria JAS, Nobre AA, Jesus SR. Prevalência e intensidade da infecção por parasitas intestinais em crianças na idade escolar na cidade de Salvador (Bahia,Brasil). Rev Soc Bras Med Trop 2001; 34(1): 99-101.

31. Monteiro CA, Chieffi PP, Benicio MHA, Dias RMS, Torres DMAGV, Mangini ACS. Estudo das condições de saúde das crianças do município de São Paulo (Brasil), 1984/ 1985. VII- Parasitoses intestinais. Rev Saude Publica 1988; 22(1): 8-15.

32. Costa-Macedo LM, Rey L. Frequency and precocity of human intestinal parasitism in a group of infants from Rio de Janeiro, Brasil. Rev Inst Med Trop São Paulo 1997; 39(5): 305-6.

33. Costa-Macedo LM, Costa MCE, Almeida LM. Parasitismo por Ascaris lumbricoides em crianças menores de dois anos: estudo populacional em comunidade do Estado do Rio de Janeiro. Cad Saude Publica 1999; 15 (1):173-8.

34. Vinha C. Distribuição geográfica da ancilostomose no Brasil. Rev Bras Malar 1968; 20: 289-318.

35. Neira P, Munoz N, Carabelli M. Enteroparasitosis en la V Region, Chile. Estudio en escolares rurales de Santo Domingo-1987. Bol Chil Parasitol 1990; 45: 24-7.

36. Ludwig KM, Frei F, Alvares-Filho F, Ribeiro-Paes JT. Correlação entre condições de saneamento básico e parasitoses intestinais na população de Assis, Estado de São Paulo. Rev Soc Bras Med Trop 1999; 32(5): 547-55.

37. Marzochi MCA. Estudo dos fatores envolvidos na disseminação dos enteroparasitas. II-Estudo da contaminação de verduras e solo de hortas na cidade de Ribeirão Preto, SP., Brasil. Rev Inst Med Trop São Paulo 1977; 19(3): 148-55.
38. Mesquita VCL, Serra CMB, Bastos OMP, Uchoa CMA. Contaminacao por enteroparasitas em hortaliças comercializadas nas cidades de Niterói e Rio de Janeiro, Brasil. Rev Soc Bras Med Trop 1999; 32(4): 363-6.

39. Coelho LM, Oliveira SM, Milman MH, Karasawa KA, Santos R. Detecção de formas transmissíveis de enteroparasitas na água e nas hortaliças consumidas em comunidades escolares de Sorocaba, São Paulo, Brasil. Rev Soc Bras Med Trop 2001; 34(5): 479-82.

40. Franco RMB, Rocha-Eberhardt R, Cantusio-Neto R. Occurence of Cryptosporidium oocysts and Giardia cysts in raw water from the Atibaia river, Campinas, Brasil. Rev Inst Med Trop São Paulo 1973; 43(2): 109-11.

41. Gonçalves A, Andrade JCR, Giribola L, Oliveira MC. Levantamento das parasitoses intestinais e condições sócio-econômicas e sanitárias em um bairro de BotucatuSP. Rev Soc Bras Med Trop 1973; 7: 25-7.

42. Arai H., Fukada Y, Hara T, Funakoshi Y, Kaneko S, Yoshida T. Prevalence of Cryptosporidium infection among domestic cats in the Tokyo metropolitan district. Japan. Jpn J Med Sci Biol 1990; 43: 7-14.

43. Genari SM, Kasai N, Pena HFJ. Occurence of protozoa and helminths in fecal samples of dogs and cats from São Paulo city. Braz J Vet Res Anim Sci 1999; 36(2): 1413-6.

44. Oshiro ET, Dorval MEC, Nunes VLB, Silva AA, Said LAM. Prevalência do Cryptosporidium parvum em crianças abaixo de 5 anos, residentes na zona urbana de Campo Grande, MS, Brasil. Rev Soc Bras Med Trop 2000; 33(3): 277-80.

45. Capelli G, Paoletti B, Iorio R, Franipane RA, Pietrobelli M, Bianciardi P, Giangaspero A. Prevalence of Giardia spp. in dogs and humans in Northern and Central Italy. Parasitol Res 2003; 90: S154-5.

46. Thompson RCA. Giardiasis as a re-emerging infectious disease and its zoonotico potential. Int J Parasitol 2000; 30: $1259-67$.

47. O'donogue PJ. Cryptosporidium and cryptosporidiosis in man and animals. Int J Parasitol 1995; 25: 139-95.

48. Fayer R, Morgan V, Upton SJ .Epidemiology of Cryptosporidium: transmission, detection and identification. Int J Parasitol 2000; 30: 1305-22.

49. Adam RD. Biology of Giardia lamblia. Clin Microbiol Rev 2001; 14(3): 447-75.

50. Monis PT, Thompson RCA. Cryptosporidium and Giardia-zoonoses: fact or fiction? Infect Genet Evol 2003; 3: 233-44.

recebido em: 17/03/06 versão final reapresentada em: 24/07/06 aprovado em: 02/08/06
Rev Bras Epidemiol 2006; 9(3): 297-308 